\title{
Role of Proteins and of Some Bioactive Peptides on the Nutritional Quality of Donkey Milk and Their Impact on Human Health
}

\author{
Silvia Vincenzetti ${ }^{1, *}$ (D), Stefania Pucciarelli ${ }^{1}$ (D), Valeria Polzonetti ${ }^{1}$ and Paolo Polidori ${ }^{2}$ \\ 1 School of Bioscience and Veterinary Medicine, University of Camerino, via Gentile III da Varano, \\ Camerino (MC) 62032, Italy; stefania.pucciarelli@unicam.it (S.P.); valeria.polzonetti@unicam.it (V.P.) \\ 2 School of Pharmacy, University of Camerino, via Circonvallazione 93, Matelica (MC) 62024, Italy; \\ paolo.polidori@unicam.it \\ * Correspondence: silvia.vincenzetti@unicam.it; Tel.: +39-073-740-2722; Fax: +39-073-740-3427
}

Academic Editor: Alessandra Durazzo

Received: 25 May 2017; Accepted: 5 July 2017; Published: 10 July 2017

\begin{abstract}
Donkey milk could be considered a good and safer alternative, compared to other types of milk, for infants affected by cow's milk protein allergy, when breastfeeding is not possible. Interestingly, donkey milk has low allergenicity, mainly due to the low total casein amount, and the content of some whey proteins that act as bioactive peptides. The amount of lysozyme, an antibacterial agent, is $1.0 \mathrm{~g} / \mathrm{L}$, similar to human milk. Lactoferrin content is $0.08 \mathrm{~g} / \mathrm{L}$, with this protein being involved in the regulation of iron homoeostasis, anti-microbial and anti-viral functions, and protection against cancer development. Lactoperoxidase, another protein with antibacterial function, is present in donkey milk, but in very low quantities $(0.11 \mathrm{mg} / \mathrm{L})$. $\beta$-lactoglobulin content in donkey milk is $3.75 \mathrm{~g} / \mathrm{L}$ - this protein is able to bind and transport several hydrophobic molecules. Donkey milk's $\alpha$-lactalbumin concentration is $1.8 \mathrm{~g} / \mathrm{L}$, very close to that of human milk. $\alpha$-lactalbumin shows antiviral, antitumor, and anti-stress properties. Therefore, donkey milk can be considered as a set of nutraceuticals properties and a beverage suitable, not only for the growing infants, but for all ages, especially for convalescents and for the elderly.
\end{abstract}

Keywords: donkey milk; bioactive peptide; whey proteins; nutritional properties

\section{Introduction}

\subsection{An Overview on Milk Composition}

Milk is a natural beverage which meets the nutritional needs of infants, since it is one of the most complete and highly nutritious foods. Nutritionally, milk is defined as "the most nearly perfect food" due to its chemical composition. The principal constituents are water, lipids, carbohydrates, and proteins (caseins and whey proteins). Furthermore, other minor constituents are present in milk, such as vitamins, minerals, hormones, enzymes, and miscellaneous compounds. As well, there are numerous immune components like growth factors, cytokines, nucleotides, antimicrobial compounds, and specific immune cells. Thanks to these features, milk provides important nutritive elements, immunological protection, and biologically active substances. The principal milk constituents vary widely among species: lipids, less than $1-55 \%$; proteins, $1-20 \%$; lactose, $0-10 \%$. Concentrations of the minor constituents are also variable. Within any species, milk composition changes among individual animals, between breeds, according to the stage of lactation, feed and health of the animal, the environment, and the climatic situation, among many other factors [1].

The composition of milk reflects mainly the nutritional and physiological requirements of the newborn, and even the profile of constituents therein changes markedly during lactation. The main 
changes are evident during the first days post-partum, especially regarding the immunoglobulin fraction. The concentration of milk components remains relatively constant during mid-lactation and changes noticeably in late lactation, due to the involution of the mammary gland tissue and the greater influx of blood constituents [2].

Among the milk constituents, fats vary widely between different species both in their concentration and chemical composition, from less than $1 \%$ in donkey milk, to more than $50 \%$ in aquatic mammals [3]. Its composition depends on the energy requirements and on the nutritional, genetic, and lactation characteristics of the species. Milk lipids are also important as a source of essential fatty acids, such as linoleic and linolenic acid, and fat-soluble vitamins A, D, E, and K.

Considering this milk fraction, although $97-98 \%$ of lipids are triacylglycerols, small amounts of di- and monoacylglycerols, free cholesterol and cholesterol esters, free fatty acids, and phospholipids are also present. Phospholipids, which represent less than $1 \%$ of total lipid, are present mainly in the milk fat globule membrane and other membranous material in the milk [4].

Regarding carbohydrate content in milk, lactose concentration varies from $0.7 \%$ to about $7.0 \%$ among the different mammal species [4].

Lactose is synthesized in the epithelial mammary cells from two molecules of glucose: one molecule of glucose is converted into UDP-galactose, which is condensed with a second molecule of glucose by the complex of lactose synthetase. The latter is a dimer composed by the UDP-galactosyl transferase and the whey protein $\alpha$-lactalbumin $(\alpha-\mathrm{La})$, which is a regulatory subunit able to make UDP-galactosyl transferase specific for glucose. Therefore, there is a positive correlation between the concentrations of lactose and $\alpha$-La in milk, (the milk of the Californian sea lion, which contains no lactose, also lacks $\alpha$-La). $\alpha$-La probably has a regulatory role in the lactose synthesis, as well as in the control of the osmotic pressure of milk [5].

Milk protein content ranges from $1 \%$ to $24 \%$ by milk weight depending on the mammalian species. There are two major categories of milk proteins that are defined by their chemical composition and physical properties: caseins and whey proteins. The caseins, which accounts for about the $80 \%$ of milk proteins in ruminants, are responsible for the transport of calcium and phosphate, and for the formation of a clot in the stomach for efficient digestion.

They are heat stable phosphoproteins synthesized in the mammary glands and found in the milk of all mammals. Caseins are divided in $\alpha$-caseins, which in turn comprise $\alpha \mathrm{s}_{1^{-}}, \alpha \mathrm{s}_{2^{-}}, \beta-$, and $\mathrm{k}$-caseins. They differ in primary structure and type and degree of post-translational modifications. These proteins are able to bind and transport relatively large amount of calcium, thanks to the presence of phosphates: this makes caseins very important for the development of teeth and bones in newborns [6].

The casein proteins are nutritionally important also because of their high content in lysine, an essential amino acid in humans: $\alpha \mathrm{s}_{1}$ - and $\alpha \mathrm{s}_{2}$-casein have 14 and 24 lysine residues, respectively.

The whey proteins are those proteins which do not precipitate from solution when the $\mathrm{pH}$ of milk is adjusted to 4.6. These proteins are referred to also as serum proteins or non-casein nitrogen, and are a heterogeneous group of heat labile globular proteins constituted mainly by $\alpha$-lactalbumin $(\alpha$-La), $\beta$-lactoglobulin ( $\beta$-LG), serum albumin and immunoglobulins, and to a lesser extent by lactoferrin and lysozyme. In the whey protein fraction, there are also enzymes, hormones, nutrient transporters, growth factors, disease resistance factors, and others. However, contrary to caseins, they do not contain phosphorus.

The ratio of casein/whey proteins is different among species-in human milk, the ratio is about 40/60, in mare's milk it is around 50/50, while in cow, goat, sheep, and buffalo's milk it is about 80/20. These differences reflect the nutritional and physiological requirements of the newborn of these species [7].

The inorganic elements are defined as macroelements or microelements, depending on whether they are present in the animal organism in smaller or greater quantities. The most important mineral salts in milk are calcium, sodium, potassium, magnesium, phosphorus (inorganic), chlorides, and citrates. Mineral elements are indispensable for the life of animals, as they participate in numerous physiological functions. 
In milk, the inorganic elements are in solution or complexed into casein micelles.

In Tables 1 and 2 are reported respectively, the quantities of the main macroelements and microelements in the milk of various species.

Table 1. Concentration of inorganic elements (mM) in the milk of different species (adapted from [8]).

\begin{tabular}{ccccccc}
\hline & Human & Bovine & Caprine & Mare & Swine & Ovine \\
\hline Calcium & 7.8 & 29.4 & 23.1 & 16.5 & 104.1 & 56.8 \\
Sodium & 5.0 & 24.2 & 20.5 & 5.7 & 14.4 & 20.5 \\
Potassium & 16.5 & 34.7 & 46.6 & 11.9 & 31.4 & 31.7 \\
Magnesium & 1.1 & 5.1 & 5.0 & 1.6 & 9.6 & 9.0 \\
Phosphorus & 2.5 & 20.9 & 15.6 & 6.7 & 51.2 & 39.7 \\
Chloride & 6.2 & 30.2 & 34.2 & 6.6 & 28.7 & 17.0 \\
\hline
\end{tabular}

Table 2. Concentration of some trace elements $(\mu \mathrm{M})$ in mare, bovine, and human milk (adapted from [9]).

\begin{tabular}{cccc}
\hline & Bovine & Mare & Human \\
\hline Zinc & 3960 & 1835 & 2150 \\
Iron & 194 & 224 & 260 \\
Copper & 52 & 155 & 314 \\
Manganese & 21 & 14 & 7 \\
Barium & 188 & 76 & 149 \\
Aluminium & 98 & 123 & 125 \\
\hline
\end{tabular}

Vitamins are important bioregulators and are classified as fat-soluble and water-soluble. They are essential compounds for nutrition as they are involved in several functions: some are hormone precursors (i.e., vitamin D), others act as antioxidants by sequestering free radicals (i.e., vitamins $C$ and $E$ ), and others constitute the prosthetic group of enzymes (i.e., vitamin B complex). Vitamin nutritional requirement varies from a few $\mathrm{mg}$, to a few $\mu \mathrm{g}$ per day, depending on the considered vitamin. In milk, vitamin content depends on the maternal vitamin status and, especially for the water-soluble vitamins, from the maternal diet. In Table 3, the content of some fat-soluble and water-soluble vitamins in the milk of various species is summarized.

Table 3. Vitamin content (mg/L) in the milk of different species (adapted from [10]).

\begin{tabular}{lccccc}
\hline Fat-Soluble Vitamins & Bovine & Caprine & Mare & Human & Ovine \\
\hline A and $\beta$-carotene & $0.32-0.50$ & 0.50 & 0.12 & 2.0 & 0.50 \\
$\mathrm{D}_{3}$, Cholecalciferol & 0.003 & - & 0.003 & 0.001 & - \\
E, $\alpha$-tocopherol & $0.98-1.28$ & - & 1.13 & 6.60 & - \\
K & 0.011 & - & 0.020 & 0.002 & - \\
Water-soluble vitamins & & & & & \\
$\mathrm{B}_{1}$, thiamine & 0.37 & 0.49 & 0.30 & 0.15 & 0.48 \\
$\mathrm{~B}_{2}$, riboflavin & 1.80 & 1.50 & 0.30 & 0.38 & 2.30 \\
$\mathrm{~B}_{3}$, niacin & 0.90 & 3.20 & 1.40 & 1.70 & 4.50 \\
$\mathrm{~B}_{5}$, pantothenic acid & 3.50 & 3.10 & 3.0 & 2.70 & 3.50 \\
$\mathrm{~B}_{6}$, pyridoxine & 0.64 & 0.27 & 0.3 & 0.14 & 0.27 \\
$\mathrm{~B}_{7}$, biotin & 0.035 & 0.039 & - & 0.006 & 0.09 \\
$\mathrm{~B}_{9}$, folic acid & 0.18 & $\mathrm{n} . \mathrm{d}$ & $\mathrm{n} . \mathrm{d}$ & 0.16 & $\mathrm{n} . \mathrm{d}$ \\
$\mathrm{B}_{12}$, cobalamin & 0.004 & 0.70 & 0.003 & 0.5 & 0.007 \\
$\mathrm{C}_{\text {, ascorbic acid }}$ & 21.0 & 9.0 & 17.2 & 43.0 & 4.25 \\
\hline
\end{tabular}

\subsection{Cow's Milk Protein Allergy}

It is well-known that the prevalence of adverse reactions to food is higher in children (6-8\% in the early years of life) than in adults (2.4\%) [11]. Prospective studies, performed in various countries, 
showed that about $2.5 \%$ of children in the first year of life have allergic reactions to cow's milk, which is therefore considered the main cause of allergies in children [12].

Cow's Milk Protein Allergy (CMPA) is clinically an abnormal immunological reaction to cow milk proteins. It may be due to the interaction between one or more milk proteins and one or more immune mechanisms, and resulting in IgE-mediated reactions. If the reactions do not involve the immune system, they are defined as cow milk protein intolerance. IgE-mediated forms are often associated with a higher risk of multiple food allergies and atopic conditions, such as asthma in later periods of life. The causes of allergy to cow's milk are manifold: first, the protein content of cow's milk is higher than that of human milk (3.6\% versus $0.9 \%-1 \%)$; second, cow's milk proteins are represented by casein for the $80 \%$ and by the whey proteins for the $18 \%$ (in human milk, $40 \%$ caseins and $60 \%$ whey proteins); third, $\beta$-lactoglobulin is absent in human milk, and for this reason, this protein is considered as a potential allergen (allergen Bos d 5).

Cow's milk caseins ( $\alpha \mathrm{s}_{1^{-}}, \alpha \mathrm{s}_{2^{-}}, \beta$ - and $\mathrm{k}$-casein) constitute the allergen Bos $\mathrm{d} 8$, however, there is a greater sensitiveness to the $\alpha$-caseins $(100 \%)$ and the $k$-casein $(91.7 \%)$. Among whey proteins, $\beta$-LG is the most abundant whey protein in cow's milk and it affects allergic patients in a percentage from $13 \%$ to $76 \%$. Also, bovine immunoglobulins (allergen Bos d 7), and in particular $\gamma$-globulin, are responsible for CMPA clinical symptoms [13]. However, the allergic reaction to cow's milk proteins occurs when these proteins are poorly digested by the infant and hence their structure remains substantially unchanged, since the polypeptide chain is not fractionated into amino acids because of insufficient protease enzymatic attack, or a lack of a specific intestine enzyme. Therefore, the undigested protein behaves as an antigen. This is not enough to determine allergic reactions, since the amount of absorbed antigen is limited by anatomical barriers (mucus, epithelium) and/or eliminated by immunological barriers, by a combination on the epithelial surface of antigen with secretory immune globulin (IgA). However, if the anatomic barriers are weakened, because of inflammatory or IgA deficiency, the penetration of large amounts of antigens occurs and the awareness and allergy in atopic subjects could increase. CMPA occurs with gastrointestinal disorders for 50-60\% of cases, skin diseases for $50-70 \%$, respiratory affections for $20-30 \%$ respirators, and anaphylaxis for $5-9 \%$ of cases [14].

Although milk allergy is considered transient, there are still some children who do not outgrow their allergy by the age of 10, but also by their adulthood [15]. These latter patients have more severe reactions and a different immunological pattern than those with transient allergy [16].

Once CMPA has been established, the therapy, as in all food allergies, should consist of the absolute exclusion of milk or allergenic proteins of the cow's milk (formulated milk and derivatives), whereas in the case of breastfed children, on the complete elimination of milk protein from the mother's diet [17].

When breast milk is insufficient or unavailable, it is indispensable to choose an alternative milk formula. In the case of infants affected by CMPA, the elimination of allergen administration usually leads to the disappearance of the symptoms. However, some patients may also show the allergic reaction if a substitute for cow's milk is used, thus indicating multiple food allergies [18].

Multiple food allergies are difficult to treat-elimination from the diet of some nutrients, if not properly balanced by the assumption of alternative nutrients, can lead to malnutrition and therefore can stop growing [18].

\section{Donkey Milk and Its Hypoallergenic Properties}

Donkey milk was greatly appreciated for its benefits and versatility as a food for newborns since ancient times, but only recently, scientific research has proven its importance in human nutrition. This is especially for some categories of the population as the elderly and the infants affected by CMPA.

\subsection{Historia Docet}

In ancient Egypt, as evidenced by the images of bas-reliefs and painting from that time, donkeys were very important for their use in agriculture and for daily works (Figure 1). 


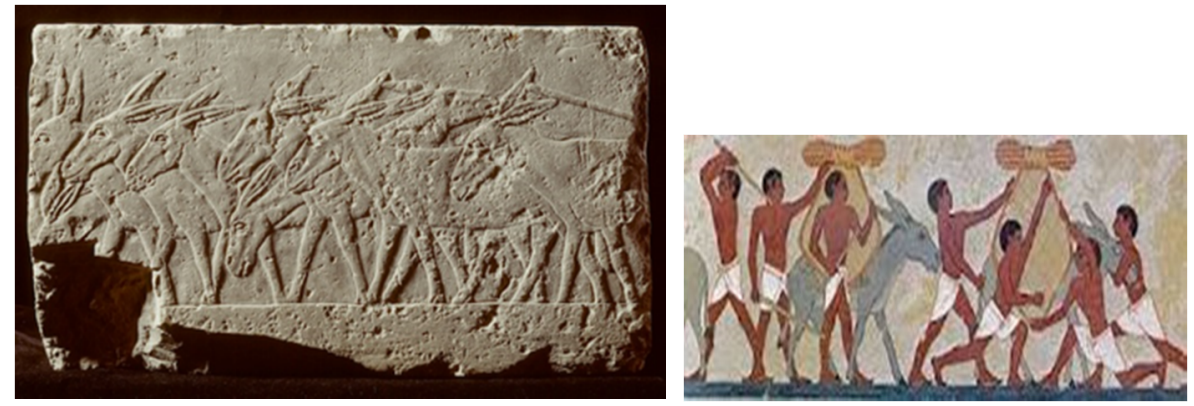

Figure 1. A bas-relief and a panting from ancient Egypt showing the use of donkeys for daily works.

The ancient Greeks considered donkey milk an excellent drug. In the 5th century BC, Herodotus estimated it as a nutritious beverage, whereas Hippocrates recommended it as a medicine capable of resolving several afflictions. Ancient Romans consumed donkey milk as a delicious drink and Pliny the Elder described its virtues regarding skin wellness: "It is believed that the donkey's milk eliminates skin wrinkles and makes the face softer and whiter. Some women are known to care for their face seven times a day, paying close attention to this number." For this purpose, it is well-known that Cleopatra and Poppaea used to immerse themselves in donkey milk to preserve their youth. In particular, Poppaea, the wife of Nero, used donkey milk every day for the bath and for this reason, she carried back 500 donkeys every time she left for a trip. It is said that Messalina also loved these "baths of beauty" for the anti-wrinkle action that she guaranteed on the skin [19]. In Asia, Africa, and Europe, it is possible to find testimonies and documents describing the properties of donkey milk, decanted for its therapeutic, cosmetic, and food virtues. In Russia and Mongolia, the consumption of milk and donkey milk, thanks to the abundant presence of vitamins A, B, and particularly C, compensated for the low consumption of fruit, vegetables, and legumes. Nomads also used to have several donkeys and horses for their milk. Leo Tolstoy affirmed: "Mare's milk give vigor to my body and wings to my spirit". During the Renaissance, there was the first scientific consideration of this product, when Francis I of France, based on the suggestion of his doctors, successfully used donkey milk against stress and physical fatigue. In the nineteenth century, again in France, Dr. Parrot of the "Hôpital des Enfants Assistés", breastfed orphaned babies directly to the nipple of the donkey (Figure 2); moreover, in several European cities, it was possible to meet some merchants who sold donkey milk.

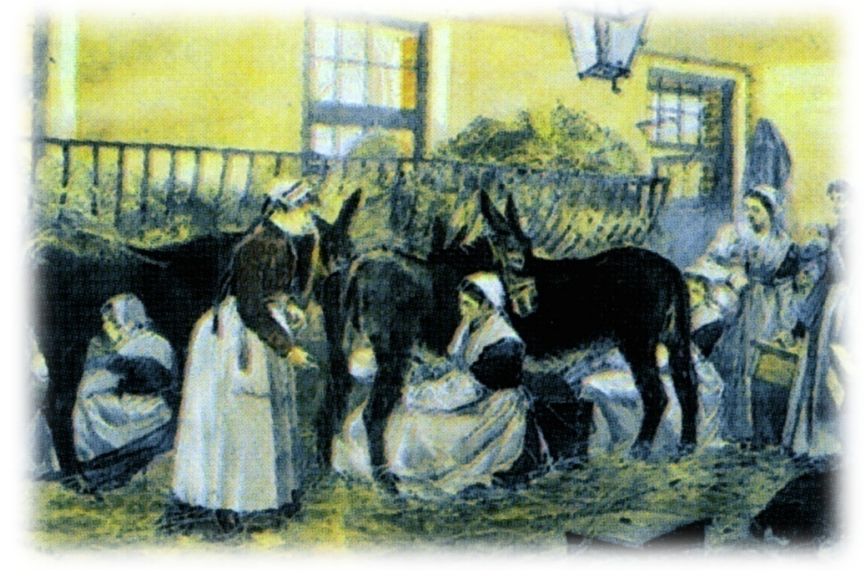

Figure 2. Collecting Ass' milk. Hôpital St. Vincent de Paul. Paris XIX century.

In those years, therefore, there was consciousness raising about the validity of donkey milk as a substitute for human milk, using it in nursing infants whenever the case requires it. This practice 
has been in use until the 1950s. In fact, during these years, it was normal to use donkey milk in cases where there was a shortage of breast milk, or when intolerance towards cow's milk was observed.

Thus, nowadays, it important to take into account the many testimonies in the past on the beneficial effects of donkey milk, but it is also important to give the right scientific approach that attests and supports its innumerable properties that are here summarized: strengthens the immune system, acts as a prebiotic on the gut flora, calms laryngeal irritation and cough, fights anaemia, fights skin problems such as psoriasis, acne, and eczema, acts on skin disorders caused by stress, and is highly digestible by newborns [20]. For these reasons, interest in donkey milk has recently begun, pressing medical research to expand its literature on this topic. On the other hand, the scientific community inherits a knowledge from the historical tradition of its great value-in particular, the importance of donkey milk as the most suitable for infant feeding as it is the closest to human milk, its high nutritional qualities, and high digestibility.

\subsection{Donkey Milk and Its Affinity with Human Milk}

It is well-known that among mammals, every species produces a kind of milk that is specific to their newborns, ensuring them the optimal nutrition. This is also true for humans. The best milk for an infant is breast milk, which responds perfectly to the needs of healthy growth and harmonious development. However, when it is not possible to breastfeed, and especially in the case of CMPA, it is necessary to find a safe and valid alternative milk that meets the needs of the infant. The various kinds of alternative milk are certainly valid and ensure good child growth, however, sometimes they are characterized by an unpleasant taste and a high cost. Further, in the case of multiple food allergies, may themselves cause unwanted allergic reactions. Donkey milk is considered a milk similar to human milk, especially regarding its protein composition. Therefore, as well as breast milk, it is able to respond to all the food needs of the newborn. Donkey milk is also an important food in the geriatric field and in cases of calcium deficiency [21].

Some studies have shown that donkey milk, which has the organoleptic characteristics closer to breast milk, may be the treatment of choice in children with food allergies in early life, who often do not respond to other therapies. Unlike other breast milk substitutes, characterized by nutritional deficiencies and induction of allergic reactions, this natural food proves to be able to nourish infants at low risk of allergenicity and also allows for the development of a normal and complete immune system [22]. With this in mind, we can consider donkey milk not simply as a food, but as a nutraceutical. We consider it to be used not only in early childhood nutrition, but also as a supplement in the diet of adults and the elderly.

In Table 4, the average percentage composition ( $\mathrm{g} / 100 \mathrm{~g}$ ) of donkey milk (evidenced in bold) is shown, compared to that of human, bovine, mare, ovine, and caprine milk $[23,24]$. The fat content in donkey milk is very close to that of mare milk, but low when compared to that of other species, including human milk. As a consequence, the average energy value found in donkey milk is $1939.4 \mathrm{~kJ} / \mathrm{kg}$, similar to that of mare's milk, but lower with respect to the milk of other species [25]. This low energy value could be a problem for the infant's energy intake if the diet of the latter is based only on donkey milk. However, this problem could be overcome through a supplement of medium-chain triglycerides or sunflower oil in the milk [26,27]. Regarding the lipid composition, donkey milk contains a lower amount of saturated fatty acid (SFA) and higher level of essential fatty acid (EFA) than that of bovine milk, and a high polyunsaturated fatty acids (PUFA) content (especially $\alpha$-linolenic acid and linoleic acid). Furthermore, this milk is characterized by a low ratio of $n-6$ to $n-3$ fatty acids $[28,29]$.

The total donkey milk dry matter is $9.61 \%$, ashes corresponding approximately to $0.43 \%$. The proportion of non-protein nitrogen is very close to that found in human milk. The biological significance of the non-protein fraction is not well clarified. However, this fraction includes urea, uric acid, creatinine, nucleic acids, amino acids, and nucleotides, which seem to be very important for neonatal development [30]. 
Table 4. Percentage composition (g/100 g) of donkey milk (evidenced in bold) and comparison with other species.

\begin{tabular}{cccccccc}
\hline Milk & Water & Dry Matter & Fat & Proteins & Lactose & Ashes & Energy Value (kJ/kg) \\
\hline Human & 87.57 & 12.43 & 3.38 & 1.64 & 6.69 & 0.22 & 2855.6 \\
Donkey & $\mathbf{9 0 . 3 9}$ & $\mathbf{9 . 6 1}$ & $\mathbf{1 . 2 1}$ & $\mathbf{1 . 7 4}$ & $\mathbf{6 . 2 3}$ & $\mathbf{0 . 4 3}$ & $\mathbf{1 9 3 9 . 4}$ \\
Mare & 90.48 & 9.52 & 0.85 & 2.06 & 6.26 & 0.35 & 1877.8 \\
Bovine & 87.62 & 12.38 & 3.46 & 3.43 & 4.71 & 0.78 & 2983.0 \\
Caprine & 86.77 & 13.23 & 4.62 & 3.41 & 4.47 & 0.73 & 3399.5 \\
Ovine & 80.48 & 19.52 & 7.54 & 6.17 & 4.89 & 0.92 & 5289.4 \\
\hline
\end{tabular}

Adapted from [23,24].

Donkey milk contains a high level of lactose, which is involved in bone mineralization. Its lactose concentration, in particular, is close to that of human milk [22]. It is also responsible for the sweet taste of donkey milk, which is much more pleasing to the palate of the newborn with respect to the other breast milk substitutes. Lactose stimulates the intestinal absorption of calcium in the infant because in these subjects, the enzyme $\beta$-galactosidase (which hydrolyses lactose into galactose and glucose) is highly expressed. Some studies in fact demonstrated that $\beta$-galactosidase-deficient subjects absorbed less calcium than $\beta$-galactosidase-normal subjects because are the hydrolytic products of $\beta$-galactosidase (glucose and galactose) that promote the calcium absorption [31,32]. Therefore, even after weaning, if a balanced diet is followed, donkey milk favors bones mineralization.

Finally, the presence of lactose makes donkey milk a suitable substrate for the preparation of fermented beverages [33].

Considering donkey milk protein content, the average of total caseins and whey proteins contents were found similar to those of human milk, but lower when compared to bovine milk (Table 5).

The content of casein was found to be slightly higher in donkey milk than in human milk, but significantly lower than that of sheep and bovine milk (Table 5). Moreover, the ratio casein/whey proteins were higher in donkey milk than human milk, but were closer to that of breast milk substitution products. In contrast, in ruminant milk, this ratio is four times higher than that of donkey milk and seven times greater than that of humans [34].

From the evaluation of the sequence homologies of $\alpha \mathrm{s}_{1}$-casein and $\beta$-casein from donkey, human, and cow, the highest homology was found between the donkey and human species both for $\alpha 1$-casein (42\% donkey/human versus $31 \%$ cow/human) than for $\beta-C N$ ( $57 \%$ donkey/human vs. $54 \%$ cow/human) [35]. This data, strictly dependent on the amino acid sequence of the comparative proteins, together with the low quantitative level of these two fractions in the donkey milk, justifies and demonstrates the best tolerability of the milk of this species.

In order to find out more information about the nutritional properties and the hypoallergenic value of donkey milk, several studies have been conducted in recent years in order to examine the protein component of this nutritionally important beverage.

\section{Bioactive Proteins and Peptides in Donkey Milk}

In Table 5 are listed in detail the different protein fractions (caseins and whey proteins) identified in donkey milk, together with the respective amount $(\mathrm{g} / \mathrm{L})$. Donkey's milk presents an amount of $\alpha$-La rather close to that determined in human milk a high amount of $\beta$-LG, which is completely absent in human milk. This whey protein has been indicated, as mentioned, as the major allergen of cow's milk, together with caseins.

This data could affect the hypoallergenic potential of donkey milk, although the cases where this milk has been used in the treatment of CMPA have proved its efficacy with very high percentages of resolution of the allergic problem. The hypothesis formulated by several pediatricians is that caseins are the main responsible of CMPA, while $\beta$-LG plays a much smaller role in the occurrence of this pathology. 
Table 5. Main proteins content in donkey milk (evidenced in bold) and comparison with bovine, caprine, and human milk.

\begin{tabular}{lcccc}
\hline & ${ }^{\mathbf{a}}$ Bovine $(\mathbf{g} / \mathrm{L})$ & ${ }^{\mathbf{b}}$ Donkey $(\mathrm{g} / \mathrm{L})$ & ${ }^{\mathrm{c}}$ Caprine $(\mathrm{g} / \mathrm{L})$ & ${ }^{\mathrm{a}}$ Human $(\mathrm{g} / \mathrm{L})$ \\
\hline Total protein content & 32.0 & $\mathbf{1 3 - 2 8}$ & $28-32$ & $9-15$ \\
Total caseins & 27.2 & $\mathbf{6 . 6}$ & 25.0 & 5.6 \\
Total whey proteins & 4.5 & $\mathbf{7 . 5}$ & 6.0 & 8.0 \\
$\alpha \mathrm{s}_{1}$-casein & 10.0 & $\mathbf{n . d .}$ & 10.0 & 0.8 \\
$\alpha \mathrm{s}_{2}$-casein & 3.7 & $\mathbf{n . d .}$ & 3.0 & - \\
$\beta$-casein & 10.0 & $\mathbf{n . d .}$ & 11.0 & 4.0 \\
K-casein & 3.5 & trace & 4.0 & 1.0 \\
$\alpha$-lactalbumin & 1.2 & $\mathbf{1 . 8 0}$ & 6.0 & $1.9-2.6$ \\
$\beta$-lactoglobulin & 3.3 & $\mathbf{3 . 7}$ & 1.2 & - \\
Lysozyme & trace & $\mathbf{1 . 0}$ & trace & $0.04-0.2$ \\
Lactoferrin & 0.1 & $\mathbf{0 . 0 8}$ & $0.02-0.2$ & $1.7-2.0$ \\
Immunoglobulins & 1.0 & $\mathbf{n . d .}$ & 1.0 & 1.1 \\
Albumin & 0.4 & n.d. & 0.5 & 0.4 \\
\hline
\end{tabular}

${ }^{\mathrm{a}}[36]{ }^{\mathrm{b}}[37,38] ;{ }^{\mathrm{c}}[39]$.

Of note is the lysozyme content in the donkey milk, in a quantity significantly greater than that one determined in human milk; this peptide has a bactericidal action, since it breaks the bacterial cell wall. It is also believed that the high presence of this compound gives the donkey milk the peculiarity of preserving its organoleptic and especially microbiological characteristics for a long time unchanged.

Donkey milk whey proteins content was also checked during the lactation period [37] (Table 6). Lysozyme amount decreased linearly during lactation - this protein is a natural antimicrobial agent; therefore, its amount tends to be higher after parturition with respect to the end of lactation. This is in order to ensure to the newborn an adequate protection against bacterial agent, since in the first days of life, the immune system of the child is not mature. $\alpha$-La content doubles up to the nineteenth day of lactation then stabilizes-this behavior reflects the important role of this protein in the lactose synthesis. Finally, the content of $\beta$-LG remains stable during lactation.

Table 6. Content ( $\mathrm{g} / \mathrm{L}$ ) of lysozyme, $\beta$-LG and $\alpha$-La in donkey milk collected in different stages of lactation.

\begin{tabular}{cccc}
\hline Lactation Period & $\beta$-LG & $\alpha$-La & Lysozyme \\
\hline 60 & n.d. & 0.81 & 1.34 \\
90 & 4.13 & 1.97 & 0.94 \\
120 & 3.60 & 1.87 & 1.03 \\
160 & 3.69 & 1.74 & 0.82 \\
190 & 3.60 & 1.63 & 0.76 \\
\hline \multicolumn{4}{c}{ Adapted from [37]. }
\end{tabular}

In the following paragraphs will be discussed in more detail the protein/peptide components of donkey milk, their potential nutraceutical function, and their impact on human health.

\subsection{Casein Fraction}

Donkey milk casein fraction is represented mainly by $\alpha s_{1}$ - and $\beta$-caseins, which showed a great variability due to the degree of phosphorylation and the presence of genetic variants. The composition of donkey milk caseins has been the subject of several studies performed by one-dimensional electrophoresis, two-dimensional electrophoresis, structural MS analysis, and reversed phase-HPLC $[38,40,41]$. The presence of $\alpha s_{2}$-casein and k-casein was also found in donkey milk even if at small amounts [40,41]. By two-dimensional electrophoresis were found more than 14 protein spots, which were in turn found corresponding mainly to $\alpha s_{1}$-casein and $\beta$-casein, as also evidenced by reversed phase-HPLC $[37,38]$. Donkey milk $\beta$-caseins showed a $\mathrm{pI}$ ranging from 4.63 to 
4.95 and a Mr varying from 33.74 to $31.15 \mathrm{kDa}$. This heterogeneity is due to the presence of two genetic variants of $\beta$-casein: a full length one characterized by the presence of $7,6,5$ phosphate groups and $\mathrm{pI}$ range of 4.74-4.91 and a spliced variant (-923 amino acids) carrying 7, 6, 5 phosphate groups and a pI range of 4.72-4.61. By two-dimensional electrophoresis experiments were found five $\alpha \mathrm{s}_{1}$-casein in donkey milk: three of them showed similar molecular weight (about $31.15 \mathrm{kDa}$ ) but different pIs (range $5.15-5.36)$, the other two showed a lower molecular weight (27-28 kDa) and pI of 5.08 and 4.92 [38]. Also in the case of $\alpha \mathrm{s}_{1}$-casein the heterogeneity is due to the presence of 5, 6 and 7 phosphate groups and non-allelic spliced forms [41]. These latter authors found in donkey milk the presence of at least four $\alpha s_{1}$-casein main components, six $\beta$-casein components, three $\alpha s_{2}$-casein components (containing 10,11 , and 12 phosphate groups), and eleven $\mathrm{k}$-caseins (evidenced after specific immunostaining). In the case of $\mathrm{k}$-casein, this high heterogeneity is probably due to a different glycosylation pattern [41].

In Table 7 are summarized the casein component until found in donkey milk.

Table 7. Donkey milk casein components. The data reported in this table were obtained from: $[38,40,41]$.

\begin{tabular}{ccc}
\hline Casein & Mr (kDa) & pI \\
\hline$\beta$-casein (full-length) & 33.74 & 4.63 \\
$\beta$-casein (full-length) & 33.54 & 4.72 \\
$\beta$-casein (full-length) & 33.10 & 4.82 \\
$\beta$-casein (full-length) & 33.54 & 4.92 \\
$\beta$-casein (spliced) & 31.66 & 4.68 \\
$\beta$-casein (spliced) & 31.48 & 4.80 \\
$\beta$-casein (spliced) & 32.15 & 4.88 \\
$\beta$-casein (spliced) & 31.15 & 4.95 \\
$\alpha \mathrm{s}_{1}$-casein (full-length) & 31.20 & 5.15 \\
$\alpha \mathrm{s}_{1}$-casein (full-length) & 31.14 & 5.23 \\
$\alpha \mathrm{s}_{1}$-casein (full-length) & 31.14 & 5.36 \\
$\alpha \mathrm{s}_{1}$-casein (spliced) & 28.26 & 5.08 \\
$\alpha \mathrm{s}_{1}$-casein (spliced) & 27.24 & 4.92 \\
$\alpha \mathrm{s}_{2}$-casein & 26.83 & n.d. \\
$\alpha \mathrm{s}_{2}$-casein & 26.91 & n.d. \\
$\alpha \mathrm{s}_{2}$-casein & 26.99 & n.d. \\
Eleven $\kappa$-caseins & n.d. & n.d. \\
\hline
\end{tabular}

\subsection{Whey Protein Fraction and Its Impact on Human Health}

Whey protein fraction has been well characterized in donkey milk by several authors. Some proteins possess important nutraceutical properties and may be beneficial for human health.

Hereafter, the main milk whey proteins are described separately and in detail.

\subsection{1. $\beta$-Lactoglobulin}

$\beta$-lactoglobulin ( $\beta-\mathrm{LG}$ ) is the most represented whey protein in ruminants and is also present in milk of some but not all species. It is not found in the milk of rodent, human, and lagomorph. In donkey milk $\beta$-LG content is $3.75 \mathrm{~g} / \mathrm{L}$, a value very close to that found in bovine milk $(3.3 \mathrm{~g} / \mathrm{L})$ and mare milk. A proteomic study was performed by two-dimensional electrophoresis, evidenced in at least three main isoforms of donkey milk $\beta$-LG which differ in relative molecular mass $\left(\mathrm{M}_{\mathrm{r}}\right)$ and $\mathrm{pI}$ value ( $\mathrm{M}_{\mathrm{r}} / \mathrm{pI}$ : 21.9/4.46; 20.0/4.40; 20.58/4.12) [38] (Figure 3).

Other authors revealed that in donkey milk $\beta$-LG exists in two isoforms: $\beta$-lactoglobulin I ( $\beta$-LGI the major form, $80 \%$ ), and $\beta$-lactoglobulin II ( $\beta$-LGII, present in minor amount) $[42,43]$. Other studies found the presence of one genetic variant of $\beta$-LGI ( $\beta$-LGIB), two genetic variants of $\beta$-LGII (namely $\beta$-LGIIB and $\beta$-LGIIC), and a third minor $\beta$-LGII variant ( $\beta$-LGIID) [44,45]. $\beta$-LG is a small protein with 162 amino acid residues $(\mathrm{Mr} \sim 18.4 \mathrm{kDa})$-its sequence and its three-dimensional structure (it is a dimer) show that it is part of the family of lipocalins which includes a large and diversified group of over 50 extracellular proteins that originate from a large variety of tissues in 
animals, plants, and bacteria. A typical lipocalin consists of a peptide chain of 160-180 amino acids, folded into 8 antiparallel filaments that produce a $\beta$-sheet arranged in a conical structure called $\beta$-barrel, in which is located the hydrophobic pocket, able to bind different hydrophobic molecules. In fact, members of this family are characterized by some common molecular properties: the ability to bind several small hydrophobic molecules, the ability to bind to specific cell surface receptors, and the ability to form complexes with soluble macromolecules. For these reasons, lipocalins can act as specific transporters, for example, for serum retinol-binding protein (RBP) [46]. The high affinity of $\beta$-lactoglobulin for a wide range of compounds and its high amount in milk has suggested several functions for this protein. In addition to transporting hydrophobic molecules, this protein seems to be involved in enzyme regulation, and in the neonatal acquisition of passive immunity [46].

Mr/pI: 21.9/4.46

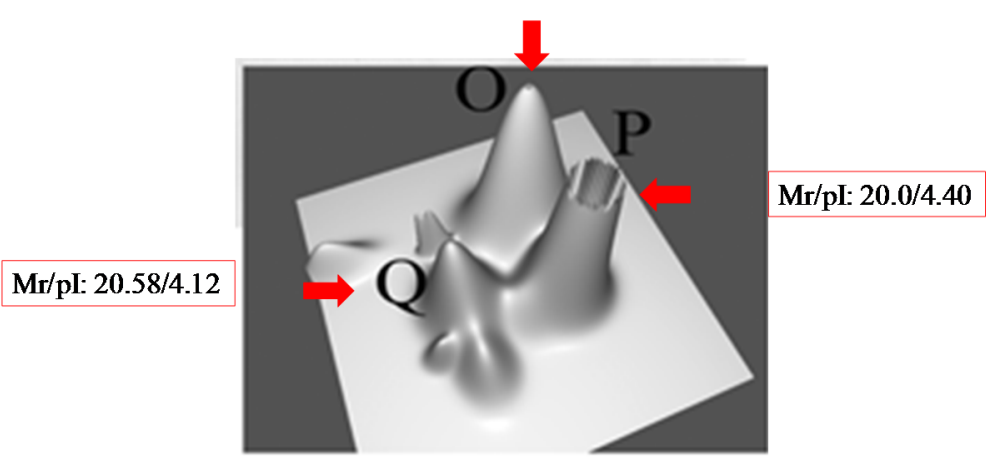

Figure 3. The three main isoforms of $\beta$-lactoglobulin, detected by two-dimensional electrophoresis. Adapted from [38].

As regard to the hydrophobic ligands, they are mainly represented by long chain fatty acids, retinol, and steroids. In milk, fatty acids, rather than retinol, represent endogenous ligands; the latter, however, being more soluble in fat, is indirectly transferred from the mother to the newborn through the $\beta$-LG. However, the effective role of this protein is not certain. This is due to two main reasons: the first is given by the presence of other lipocalins that have a similar function, the second being a simple reasoning based on the fact that if $\beta$-LG played an indispensable role, it would be expressed in all mammalian species and not just in some. One hypothesis on the role of this protein may be that the real $\beta$-LG function may be related to the physiology of the mother, rather than to that of the newborn.

An important issue has been the identification in cow and goat of a pseudo-gene (ancestral genes that have lost their ability to be expressed), which appeared very similar to the equine $\beta$-LG-II sequence [46]. An explanation of the presence of the pseudo-gene could be that the protein served for its true function elsewhere then it may be expressed in the mammary gland of some species (but not all) as source of nutrition.

Kontopidis and co-workers [46] examined the $\beta$-LG sequences of the various species together with the other lipocalins, creating a genealogical tree from which they noted that RBPs are clearly distinct from the lactoglobulins, with the exception of a single protein: the glycodelin. This is a protein expressed in a large amount during human pregnancy (first three months) in the endometrium and seems to be involved in immunosuppression and/or cellular differentiation.

Therefore, it could be possible to postulate that in many species this gene has undergone a duplication event and now it is expressed during lactation for nutritional purposes. Likewise, in some species, such as rodents, lagomorphs, and humans, the formation of a pseudogene has ceased, and consequently ceased its presence in the milk of these species [46].

Recently it was shown by Liang and co-workers [47] that $\beta$-LG is able to interact with resveratrol, a natural polyphenolic compound with antioxidant activity forming a 1:1 complex that enhances the 
photostability and hydrosolubility of resveratrol, improving its bioavailability. Furthermore, it has been shown that $\beta$-LG is able to form complexes also with folic acid; therefore, it may be used as an effective carrier of this important vitamin in food [48].

\subsection{2. $\alpha$-Lactalbumin}

Donkey milk contains a considerable amount of $\alpha$-La with a concentration of $1.80 \mathrm{~g} / \mathrm{L}$, very close to the amount found in human and bovine milk [37]. Thanks to two-dimensional electrophoresis it was possible to identify in donkey milk the presence of two isoforms of $\alpha$-La that showed different pI values: 4.76 and 5.26 [38]. The presence of two isoforms in donkey milk was already observed by Cunsolo and co-workers [45], who found oxidized methionine (at position 90 of the amino acid sequence) form for $\alpha$-La, which presumably derive by in vivo oxidative stress.

$\alpha$-La is a small protein ( $\mathrm{Mr} 14.2 \mathrm{kDa}$ ), with a binding site with $\mathrm{Ca}^{2+}$ ion. It has been hypothesized that $\alpha$-La gene originated 300-400 million years ago from an ancestral lysozyme gene, by gene duplication. This is the reason why $\alpha$-lactalbumin shares $40 \%$ sequence identity with lysozyme (also their three-dimensional structure looks very similar).

This protein consists of two domains: one large $\alpha$-helical domain and another one smallest constituted by $\beta$-sheet. These two domains are linked together by calcium binding loop. Further, they are held together by a disulphide bridge between cysteine residue 73 and 91, which forms also the calcium binding loop, and another disulphide bridge between 61 and 77 cysteine residues. Definitively, the overall structure of $\alpha$-La is stabilized by four disulphide bridges [49].

This protein is important for various reasons. First of all, $\alpha$-La is part of the enzymatic complex that regulates lactose synthesis in the breast gland and also facilitates the absorption of lactose in the intestine. However, $\alpha$-La has myriad of other functions, among all anti-inflammatory and antinociceptive functions. Some authors showed that the proteolytic digest of $\alpha$-La released three peptides with bactericidal properties. In particular, two fragments were obtained from the tryptic digestion and the third one was obtained by fragmentation of $\alpha$-La by chymotrypsin. These polypeptides were mainly active against Gram-positive bacteria, whereas they were less active on Gram-negative bacteria. If $\alpha$-La was digested by pepsin, the polypeptide fragments obtained did not show any antibacterial activity. Since undigested $\alpha$-La does not possess bactericidal activity, it was suggested as a possible antimicrobial function of $\alpha$-lactalbumin only after its partial digestion by endopeptidases [50].

Other authors purified a $\alpha$-La folding variant from human milk with bactericidal activity against antibiotic-resistant strains of Streptococcus pneumoniae. In these experiments, the native $\alpha$-La was converted to the active bactericidal form by anion-exchange chromatography in the presence of a C18:1 fatty acid (oleic acid) [51]. However, this antibacterial activity was selective only for streptococci-in fact, Gram-negative and other Gram-positive bacteria resulted resistant.

Finally, it was demonstrated that native $\alpha$-La possesses several classes of fatty acid binding site [52].

Some multimeric human $\alpha$-La derivative induces an increase of $\mathrm{Ca}^{2+}$ level and acts as an apoptosis-inducing agent $[53,54]$. In fact, it has been shown that multimeric $\alpha$-La can bind to the cell surface, enter in the cytoplasm and accumulate in the nuclei. Further, the direct interaction of $\alpha$-La with mitochondria lead to cytochrome c release, which, in turn, start the caspase cascade which is involved in apoptosis [55].

In particular, it has been shown that in human milk the $\alpha$-lactalbumin-oleic acid complex, called HAMLET (Human $\alpha$-lactalbumin Made Lethal to Tumor Cells), is capable of inducing selective apoptosis towards cancer cells, but leaves fully differentiated cells unaffected. The in vivo effects of HAMLET have been investigated in patients and in tumor cell lines, and the results indicated that HAMLET limits the progression of human glioblastomas in a xenograft model and removes skin papillomas in patients. In tumor cells, HAMLET enters the cytoplasm and then enters the nuclei where it accumulates. Here, HAMLET binds to histones and disrupts chromatin organization [56]. 
Furthermore, it has been shown that the acid $\mathrm{pH}$ in the stomach of the breast-fed child can promote the formation of HAMLET, which contribute to the protective effect of breastfeeding against childhood tumors [56].

HAMLET can be produced starting from a purified native $\alpha$-lactalbumin which is initially partially unfolded by ethylenediaminetetraacetic acid (EDTA), a chelating agent able to remove the calcium ion. The protein adopts the apo-conformation that exposes a new fatty acid binding site, which has high specificity for oleic acid.

Subsequently, the protein is subjected to an ion-exchange chromatography on a matrix conditioned with oleic acid, which binds to $\alpha$-La and stabilize the altered protein conformation. The complex eluted from the column in presence of high salt solution is the HAMLET complex [56].

\subsubsection{Lysozyme}

In donkey milk, lysozyme has been purified and characterized by a reversed-phase HPLC, followed by a $15 \%$ polyacrylamide gel electrophoresis under denaturing conditions (15\% SDS-PAGE). Two-dimensional electrophoresis revealed the presence of one spot corresponding to the lysozyme, with a $\mathrm{Mr}$ of $14.5 \mathrm{kDa}$ and a $\mathrm{pI}$ of $9.40[37,38]$. However, in the literature are reported the presence of two isoforms of donkey milk lysozyme: lysozyme A (Mr $14.631 \mathrm{kDa})$ and lysozyme B (Mr $14.646 \mathrm{kDa}$ ), which differ for an oxidized methionine at position 79 . This derives, most likely, from a post-translational modification [44,45]. Donkey milk contains $1.0 \mathrm{~g} / \mathrm{L}$ of lysozyme (higher with respect to the lysozyme content of human milk), while in goat and bovine milk this protein is virtually absent. Lysozyme belongs to the class of hydrolases, and specifically is a glycosidase. It has a structure consisting of two domains: one domain is essentially composed of $\alpha$-helices, and the other consists of an anti-parallel $\beta$-sheet and two $\alpha$-helices. The three-dimensional configuration of the molecule is maintained by the presence of three disulphide bridges: two located in the alpha-helix domain, and one in the $\beta$-sheet. In its inner part there are few polar residues.

Under the bioactive aspect, this enzyme exerts a bactericidal action, as it disrupts the cell wall of the microorganisms; its hydrolytic reaction occurs only on the O-glycosyl compounds. This results in the cleavage of the glycoside bond between the carbon 1 of the glucosamine and the carbon 4 of the muramic acid, thereby causing the broken of bacterial cell wall.

Various experiments have shown that due to the high content of lysozyme in donkey milk, raw milk of this species, different to raw cow milk, does not change its organoleptic and microbiological characteristics over time. This suggests a long shelf life of donkey milk which could be stored longer with respect to raw cow milk [57]. In another study on the antimicrobial properties of donkey milk, Šarić and co-workers found a positive correlation between the high content of lysozyme and the antibacterial activity against Listeria monocytogenes and Staphylococcus aureus [58].

Furthermore, thanks to its bactericidal action, lysozyme may help to prevent intestinal infections in infants, thus facilitating a proper digestion and normal absorption of nutrients.

In addition, it has been shown that this enzyme has other physiological functions: anti-inflammatory activity, immunoregulatory activity, and antitumor activity. In particular, studies have shown that lysozyme inhibits angiogenesis and has antitumor activity. Recent in vitro studies have noted an anti-proliferative and antitumor activity of donkey milk against the adenocarcinoma human alveolar basal epithelial cells (A549) through the stimulation of IL-2, IFN-g, IL-6, TNF-a, and IL- $1 \mathrm{~b}$ cytokines production, the modification of the cell cycle, and the induction of the apoptosis process [59]. Furthermore, it has been shown that equine lysozyme, which, as discussed before, is structurally homologous to $\alpha$-lactalbumin, can form complexes with oleic acid called ELOA (equine lysozyme and oleic acid). This, in analogy to the HAMLET complex, may show cytotoxic activity. Recently, it has been shown that ELOA also displays bactericidal activity against pneumococci-in particular these complex binds to Streptococcus pneumoniae, causing perturbations of the plasma membrane, such as depolarization and rupture, and consequently calcium enters the cells. As discussed before, the increase of intracellular calcium induces apoptosis. Furthermore, analogously to HAMLET, 
ELOA-induced apoptosis is accompanied by DNA fragmentation into high molecular weight fragments [60]. Equine lysozyme also possesses the high-affinity calcium-binding site of $\alpha$-lactalbumin, whose amino acid sequence is highly conserved [56].

\subsubsection{Lactoferrin}

Lactoferrin, also called lactotransferrin, is an $80.0 \mathrm{kDa}$ glycoprotein belonging to the transferrin family, is an iron-chelating glycoprotein, and has a structure composed of two homologous domains, each binding a ferric ion $\left(\mathrm{Fe}^{3+}\right)$ and a carbonate anion. It is a protein that shows several functions, including regulation of iron homoeostasis, cell growth and differentiation, defense against infectious agents, anti-inflammatory and cancer protection, and ultimately a trophic activity on the intestinal mucosa [61]. Lactoferrin is present mainly in milk, and also in small quantities in exocrine fluids such as saliva, tears, bile, seminal fluid, and pancreatic juice. The plasma contains a low concentration of lactoferrin, but during inflammatory reactions, the neutrophil granulocytes release this protein by increasing the concentration of the plasma pool. Lactoferrin concentration is quite high in human milk $(1.0 \mathrm{mg} / \mathrm{mL})$ compared with bovine milk $(0.02-0.2 \mathrm{~g} / \mathrm{L})$, sheep $(0.14 \mathrm{~g} / \mathrm{mL})$, and goat $(0.02-0.40 \mathrm{~g} / \mathrm{L})$. However, in all species, the highest lactoferrin concentration is found in the colostrum (in the human colostrum is about $7.0 \mathrm{~g} / \mathrm{L}$ ) and may increase in the case of breast infection. In mare milk, lactoferrin concentration is about $0.10 \mathrm{~g} / \mathrm{L}$, while in colostrum ranges from 1.5 to $5.0 \mathrm{~g} / \mathrm{L}$. In donkey milk was found a lactoferrin concentration of $0.08 \mathrm{~g} / \mathrm{L}$, close to that of mare milk, cow, and goat, but lower than the average concentration found in human milk [38]. Lactoferrin shows two different mechanisms of antimicrobial activity. The first mechanism has a bacteriostatic effect, because, thanks to its high affinity with iron, it can subtract this metal to iron-dependent bacteria, which are thus deprived of essential nutritious growth. Thanks to its bacteriostatic properties, due to the ability to bind iron, lactoferrin is capable of delaying growth to a wide variability of microorganisms, including a wide range of gram-positive and gram-negative bacteria and some type of yeasts. However, the bacteriostatic effect is often temporary because some gram-negative bacteria became able to adapt themselves to the restrictive conditions of iron through the synthesis of low molecular weight chelating agents (siderophores) that are able to remove iron from lactoferrin. The second antimicrobial activity is due to a direct-action mechanism of lactoferrin that is capable of damaging the cell wall of gram-negative bacteria, binding to lipopolysaccharide A, to the porins, and other surface molecules of the cell wall of some microorganisms. Lactoferrin has an important anti-inflammatory role associated with the microbial challenge. It has been shown through animal studies that the administration of lactoferrin protects against gastritis acting against Helicobacter pylori [62]. This protective effect against infections seems to be due to the fact that lactoferrin promotes the inhibition of several pro-inflammatory cytokines such as tumor necrosis factor alpha (TNFa), interleukin-1 $\beta$ (IL-1 $\beta$ ) and IL-6. Lactoferrin is upregulated in several inflammatory disorders such as neurodegenerative disease, arthritis, allergic skin, inflammatory bowel disease, and lung disorders [61]. Furthermore, lactoferrin, besides the many biological roles already known, stimulates the proliferation and differentiation of osteoblasts as shown by Cornish and co-workers [63].

From the digestion of lactoferrin derive some peptides with antimicrobial activity against pathogens, namely LF1-11, lactoferrampin, and lactoferricin. All of these derive from the N-terminal domain of lactoferrin and are conserved in lactoferrin of most species. The most important peptide is lactoferricin which exerts its antibacterial activity against several bacteria, viruses, fungal pathogens, and protozoa. Furthermore, this peptide displayed other activities, such as inhibition of tumor metastasis in mice and induction of apoptosis in THP-1 human monocytic leukemic cells. [64].

Comparing the antimicrobial activities of lactoferricin from human, bovine, murine, and caprine, it was shown that bovine lactoferricin was the most active. In fact, its minimal inhibitory concentration (MIC) against some Escherichia coli strains was about $30 \mu \mathrm{g} / \mathrm{Ml}$, whereas in the lactoferricin derived from human lactoferrin, IT was about 4 times higher. The higher antimicrobial activity of bovine lactoferricin seems to be due to the presence of high amounts of net positive charges 
and hydrophobic residues [64]. Another group of peptides which derives from lactoferrin digestion includes lactoferroxins. These are classified as opioid peptides, since they show effects similar to that of opiates [65]. Opioid peptides can be also obtained from the digestion of caseins (casomorphines).

\subsubsection{Lactoperoxidase}

Lactoperoxidase (LPO) is an enzyme predominantly secreted by the mammal gland, but it can be found also in other glandular secretions. This enzyme is part of the peroxidase family and is a glycoprotein consisting of 608 amino acids with a molecular mass of $78.0 \mathrm{kDa}$. Its secondary structure consists of $\alpha$-helices and two short-anti-parallel $\beta$-sheets which form, together, a spheroidal structure with a heme group in the center linked covalently. To the enzyme is also linked with a calcium ion, important for the maintaining of the protein structural integrity [66]. The LPO system catalyzes the oxidation of several substrates, by using hydrogen peroxide $\left(\mathrm{H}_{2} \mathrm{O}_{2}\right)$ as shown in the following reaction:

$$
\text { Reduced substrate }+\mathrm{H}_{2} \mathrm{O}_{2} \rightarrow \text { Oxidized product }+\mathrm{H}_{2} \mathrm{O}
$$

Reduced substrates include thiocyanate $\left(\mathrm{SCN}^{-}\right)$and iodide ions $\left(\mathrm{I}^{-}\right)$, whereas hydrogen peroxide can derive from the reaction of glucose with oxygen catalyzed by the enzyme glucose oxidase. Once formed, the oxidized products have a potent bactericidal activity against bacteria, virus, parasite, fungi, and mycoplasma [67]. LPO system has a bacteriostatic effect also on Listeria monocytogenes, therefore, it should be used for controlling the development of this bacterium in the raw milk at refrigeration temperatures. Furthermore, some authors co-administered lactoferrin and LPO to mice infected with influenza virus in order to attenuate pneumonia [68]. Thanks to its bacteriostatic activity, LPO is widely used in the preservation of food.

Donkey milk LPO enzymatic activity was $4.83 \pm 0.35 \mathrm{mU} / \mathrm{mL}$ and its amount $0.11 \pm 0.027 \mathrm{mg} / \mathrm{L}$ [38]. This value resulted 100 times lower with respect to the bovine milk LPO $(0.03-0.1 \mathrm{~g} / \mathrm{L})$, but very similar to that found in human milk $(0.77 \pm 0.38 \mathrm{mg} / \mathrm{L})[67,69]$.

The three above-mentioned protective factors (lysozyme, LPO, and lactoferrin) may have additive or synergic effects, as reported by some authors [70,71], and, as known, all of them contribute to the protection of the newborn animal. It is interesting to notice that these antimicrobial factors are almost the same in different species, but their amount and importance can vary widely. In fact, the content of lysozyme in donkey and human milk is considerably higher than that of bovine milk, whereas lactoperoxidase is present in small amounts in donkey and human milk, but is high in bovine milk (Table 8).

Table 8. Amount of the three main antimicrobial factors in human, bovine, and donkey milk.

\begin{tabular}{cccc}
\hline Milk & Lysozyme $(\mathrm{g} / \mathrm{L})$ & Lactoperoxidase $(\mathrm{mg} / \mathrm{L})$ & Lactoferrin $(\mathrm{g} / \mathrm{L})$ \\
\hline Human & 0.12 & 0.77 & $0.3-4.2$ \\
Donkey & 1.0 & 0.11 & 0.08 \\
Bovine & Trace & $30-100$ & 0.10 \\
\hline \multicolumn{4}{c}{ Adapted from [38]. }
\end{tabular}

Furthermore, it has been demonstrated that the immunoglobulins found in the milk exert a synergistic effect on the activity of these non-specific antimicrobial factors, as demonstrated by Tenuovo and co-workers [70] in the case of the LPO system, whose antimicrobial activity against Streptococcus mutans increases considerably if the system is incubated with secretory IgA. The antimicrobial activity enhancement seems to be due to a binding between LPO and immunoglobulins (IgA). The result of this interaction is a stabilization of the enzymatic activity of lactoperoxidase. 


\subsection{6. $\beta$-Casein Fragments}

Bioactive peptides derive from caseins and they possess multifunctional properties. In fact, they initially act as physiological modulators of metabolism during intestinal digestion of food and when absorbed, they can act on the various target organs of the organism. In particular, bioactive peptides play several roles in the cardiovascular, digestive, nervous, and immune systems [72].

Cunsolo and co-workers [45] found the presence of $\beta$-casein fragments in the donkey milk whey protein fraction, which can derive from the partial digestion of $\beta$-casein by endogenous proteases. In particular, these authors found that the donkey's $\beta$-casein fragment 199-226, with molecular mass of 3043.0 Da, share $40 \%$ sequence homology with the human $\beta$-casein fragment 184-210, which shows antimicrobial activity. Furthermore, the N-terminal sequence of the donkey $\beta$-casein fragment 199-226, has homology with the bovine $\beta$-casein fragment 193-198, which has anti-hypertensive properties [73] (Figure 4).

\section{A donkey \\ B bovine \\ C human}
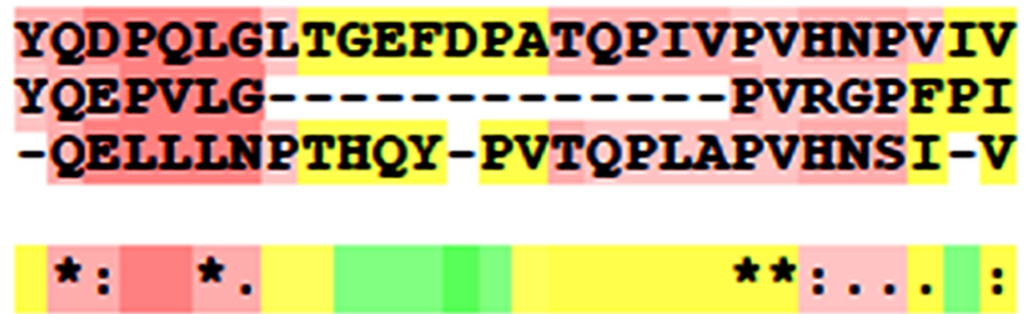

Figure 4. Alignment of fragments derived from the $\beta$-casein digestion with anti-hypertensive properties: (A): donkey's $\beta$-casein fragment 199-226; (B): human $\beta$-casein fragment 184-210; (C): bovine $\beta$-casein fragment 193-198 [45]. Sequence alignment was performed by T-COFFEE, Version_11.00 [74].

However, the function and the impact on human health of the bioactive peptides derived from donkey milk casein is not well elucidated yet. Therefore, for the time being, it is possible only to speculate on the possible function of these peptides based on sequence similarities with the peptides derived from bovine milk [45]. Some properties of bioactive peptides derived from bovine milk casein are reported below.

Some authors showed that some peptides derived from $\alpha \mathrm{s}_{1}$-casein and from $\beta$-caseins known as casokinins (particularly fragments 177-183 and 193-202) inhibit the in vitro activity of angiotensin-converting-enzyme (ACE) [75], thus acting as anti-hypertensive agents. A similar result was obtained by other authors, which showed that some peptides derived from milk whey and casein proteins possess ACE-inhibitory activity, in particular the peptides identified were from $\alpha \mathrm{s}_{1}$-casein (fragments 142-147, 157-164 and 194-199) and $\beta$-caseins (fragments 108-113, 177-183 and 193-198) [76].

The in vitro enzymatic hydrolysis of $\beta$-casein produces several peptides with opioid-like activity and characterized by a common N-terminal sequence Tyr-Gly-Gly-Phe. The presence of a Tyr residue at the $\mathrm{N}$-terminus is important for the opioid activity. The most important opioid peptides are the $\beta$-casomorphins, which are fragments of $\beta$-caseins between the 60th and 70th residues [72]. The presence of these bioactive peptide has effect on central nervous system (analgesic and sedative action), and on the endocrine system.

Furthermore, the bioactive peptides derived from caseins also show also immunomodulatory activity (stimulation of the immune system) and antimicrobial activity (inhibition of pathogens). It has been proven that the digestion of human and bovine milk caseins releases peptides with immunostimulating activity. Parker and co-workers [77] demonstrated in particular the immunomodulatory activity of the fragment 54-50 of human $\beta$-casein (hexapeptide Val-Glu-Pro-Ile-Pro-Tyr). 


\section{Conclusions}

Donkey milk could be considered a valid replacement for human milk for clinical tolerability, palatability, and nutritional adequacy for children affected by CMPA. It could also furnish additional physiological functions, such as providing antibacterial substances, digestive activity molecules, growth factors, and hormones. In children's nutrition, the use of natural milk, rather than a formula during the cow's milk free diet period, should be encouraged. In this context, it is very important that the nutraceutical role is discovered for donkey milk, because of its content of functional proteins and peptides that have immunological-like properties and are able to stimulate the functional recovery and development of the neonatal intestine. In particular, in the whey protein fraction, it is worth mentioning the presence of a good amount of $\alpha$-lactalbumin which, besides being implicated in lactose synthesis, also induces apoptosis in cancer cells when complexed with oleic acid (HAMLET) as demonstrated by in vivo and in vitro experiments. A high amount of lysozyme which shows a bactericidal action against several pathogens and, similarly to $\alpha$-lactalbumin, can form complex with oleic acid with bactericidal action called ELOA. Donkey milk contains a discrete amount of lactoferrin which display several positive effects on human health such as iron homeostasis, antimicrobial activity, cellular growth differentiation, anti-inflammatory activity, protection against cancer development, and metastasis. Furthermore, once digested in the stomach, lactoferrin is fragmented into small peptides with a more potent action against several bacteria, viruses, fungal pathogens and protozoa, with respect to the full-length lactoferrin from which they derive. Finally, in donkey milk whey protein fraction, the presence of small peptides derived from $\beta$-casein, whose sequence was found to be similar to that of peptides derived from bovine $\beta$-caseins, was demonstrated. The function of these peptides derived from donkey milk $\beta$-casein is not well elucidated yet, but it can be supposed that they may have roles on cardiovascular, digestive, nervous, and immune systems as described for the bovine counterpart.

The structural similarities between human and donkey milk proteins could contribute to explain the results of clinical studies performed by using this milk $[22,26,78]$ indicating that donkey milk may be a valid substitute of cow milk for feeding allergic children. Furthermore, the nutraceutical and functional properties determined in donkey milk could be considered valid reasons for the production of starting formulas based on donkey milk.

However, in the use of donkey milk for infant nutrition, it should also be taken into account the low lipid content, and consequently its low energetic value, which could limit the use of this kind of milk for feeding children affected by CMPA [79]. For this purpose, more clinical studies designed to evaluate the nutritional efficiency of donkey milk in the first years of life should be encouraged, since until now the case studies reported in literature are still too few.

Conflicts of Interest: The authors declare no conflict of interest.

\section{References}

1. Claeys, W.L.; Verraes, C.; Cardoen, S.; De Block, J.; Huyghebaert, A.; Raes, K.; Dewettinck, K.; Herman, L. Consumption of raw or heated milk from different species: An evaluation of the nutritional and potential health benefits. Food Control 2014, 42, 188-201. [CrossRef]

2. Thompson, A.; Boland, M.; Singh, A. Milk proteins from expression to food. In Food Sciences and Technology; Thompson, A., Boland, M., Singh, A., Eds.; Elsevier: Burlington, MA, USA, 2009; pp. 8-56.

3. Ragona, G.; Corrias, F.; Benedetti, M.; Paladini, M.; Salari, F.; Altomonte, L.; Martini, M. Amiata Donkey Milk Chain: Animal Health Evaluation and Milk Quality. Ital. J. Food Saf. 2016, 5, 5951. [CrossRef] [PubMed]

4. Fox, P.F.; McSweeney, P.L.H. Dairy Chemistry and Biochemistry; Blackie Academic and Professional: London, UK, 1998; pp. 67-71.

5. Donovan, S.M.; Monaco, M.H.; Bleck, G.T.; Cook, J.B.; Noble, M.S.; Hurley, W.L.; Wheeler, M.B. Transgenic Over-Expression of Bovine $\alpha$-Lactalbumin and Human Insulin-Like Growth Factor-I in Porcine Mammary Gland. J. Dairy Sci. 2001, 84, E216-E222. [CrossRef] 
6. Haug, A.; Høstmark, A.T.; Harstad, O.M. Bovine milk in human nutrition-A review. Lipids Health Dis. 2007, 6, 25. [CrossRef] [PubMed]

7. Rafiq, S.; Huma, N.; Pasha, I.; Sameen, A.; Mukhtar, O.; Khan, M.I. Chemical Composition, Nitrogen Fractions and Amino Acids Profile of Milk from Different Animal Species. Asian Australas. J. Anim. Sci. 2016, 29, 1022-1028. [CrossRef] [PubMed]

8. Holt, C.; Jenness, R. Interrelationships of constituents and partition of salts in milk samples from eight species. Comp. Biochem. Physiol. A Comp. Physiol. 1984, 77, 275-282. [CrossRef]

9. Anderson, R.R. Comparison of trace elements in milk of four species. J. Dairy Sci. 1992, 75, 3050-3055. [CrossRef]

10. Uniacke-Lowe, T.; Fox, P.F. Equid Milk: Chemistry, Biochemistry and Processing. In Food Biochemistry and Food Processing, 2nd ed.; Simpson, B.K., Ed.; John Wiley \& Sons, Inc.: Oxford, UK, 2012; pp. 491-528.

11. Buttriss, J. Adverse Reaction to Food. The Report of a British Nutrition Foundation Task Force; Buttriss, J., Ed.; Blackwell Science: Oxford, UK, 2002.

12. Hochwallner, H.; Schulmeister, U.; Swoboda, I.; Spitzauer, S.; Valenta, R. Cow's milk allergy: From allergens to new forms of diagnosis, therapy and prevention. Methods 2014, 66, 22-33. [CrossRef] [PubMed]

13. Pessler, F.; Nejat, M. Anaphylactic reaction to goat's milk in a cow's milk-Allergic infant. Pediatr. Allergy Immunol. 2004, 15, 183-185. [CrossRef] [PubMed]

14. Ghosh, J.; Malhotra, G.S.; Mathur, B.N. Hypersensitivity of human subjects to bovine milk proteins: A review. Indian J. Dairy Sci. 1989, 42, 744-749.

15. Giner, M.T.; Vasquez, M.; Dominiguez, O. Specific oral desensitization in children with IgE-mediated cow's milk allergy. Evolution in one year. Eur. J. Pediatr. 2012, 171, 1389-1395. [CrossRef]

16. Sánchez-García, S.; del Río, P.R.; Escudero, C.; García-Fernández, C. Efficacy of Oral Immunotherapy Protocol for Specific Oral Tolerance Induction in Children with Cow's Milk Allergy. IMAJ 2012, 14, 43-47. [PubMed]

17. Venter, C. Cow's milk protein allergy and other food hypersensitivities in infants. J. Fam. Health Care 2009, 19, 128-134. [PubMed]

18. Wang, J. Management of the Patient with Multiple Food Allergies. Curr. Allergy Asthma Rep. 2010, 10, 271-277. [CrossRef] [PubMed]

19. Cunsolo, V.; Muccilli, V.; Fasoli, E.; Saletti, R.; Righetti, R.G.; Foti, S. Poppea's bath liquor: The secret proteome of she-donkey's milk. J. Proteom. 2011, 74, 2083-2099. [CrossRef] [PubMed]

20. Jirillo, F.; Jirillo, E.; Magrone, T. Donkey's and goat's milk consumption and benefits to human health with special reference to the inflammatory status. Curr. Pharm. Des. 2010, 16, 859-863. [CrossRef] [PubMed]

21. Polidori, P.; Ariani, A.; Vincenzetti, S. Use of Donkey Milk in Cases of Cow's Milk Protein Allergies. Int. J. Child Health Nutr. 2015, 4, 174-179. [CrossRef]

22. Iacono, G.; Carroccio, A.; Cavataio, F.; Montalto, G.; Soresi, M.; Balsamo, V. Use of ass's milk in multiple food allergy. J. Pediatr. Gastroenterol. Nutr. 1992, 14, 177-181. [CrossRef] [PubMed]

23. Polidori, P.; Beghelli, D.; Mariani, P.; Vincenzetti, S. Donkey milk production: State of the art. Ital. J. Anim. Sci. 2009, 8, 677-683. [CrossRef]

24. Salimei, E.; Fantuz, F.; Coppola, R.; Chiofalo, B.; Polidori, P.; Varisco, G. Composition and characteristics of ass's milk. Anim. Res. 2004, 53, 67-78. [CrossRef]

25. Malacarne, M.; Martuzzi, F.; Summer, A.; Mariani, P. Protein and fat composition of mare's milk: Some nutritional remarks with reference to human and cow's milk. Int. Dairy J. 2002, 12, 869-877. [CrossRef]

26. Carroccio, A.; Cavataio, F.; Montalto, G.; D'Amico, D.; Alabrese, L.; Iacono, G. Intolerance to hydrolised cow's milk proteins in infants: Clinical characteristics and dietary treatment. Clin. Exp. Allergy 2000, 30, 1597-1603. [CrossRef] [PubMed]

27. Monti, G.; Viola, S.; Baro, C.; Cresi, F.; Tovo, P.A.; Moro, G.; Ferrero, M.P.; Conti, A.; Bertino, E. Tolerability of donkey's milk in 92 highly-problematic cow's milk allergic children. J. Biol. Regul. Homeost. Agents 2012, 26, 75-82. [PubMed]

28. Chiofalo, B.; Salimei, E.; Chiofalo, L. Acidi grassi nel latte d'asina: Proprietà bio-nutrizionali ed extranutrizionali. Large Anim. Rev. 2003, 6, 21-26.

29. Martemucci, G.; D'Alessandro, A.G. Fat content, energy value and fatty acid profile of donkey milk during lactation and implications for human nutrition. Lipids Health Dis. 2012, 11, 113. [CrossRef] [PubMed]

30. Vincenzetti, S.; Pucciarelli, S.; Nucci, C.; Polzonetti, V.; Cammertoni, N.; Polidori, P. Profile of nucleosides and nucleotides in donkey's milk. Nucleosides Nucleotides Nucleic Acids 2014, 33, 656-667. [CrossRef] [PubMed] 
31. Birlouez-Aragon, I. Effect of lactose hydrolysis on calcium absorption during duodenal milk perfusion. Reprod. Nutr. Dev. 1988, 28, 1465-1472. [CrossRef] [PubMed]

32. Griessen, M.; Cochet, B.; Infante, F.; Jung, A.; Bartholdi, P.; Donath, A.; Loizeau, E.; Courvoisier, B. Calcium absorption from milk in lactase-deficient subjects. Am. J. Clin. Nutr. 1989, 49, 377-384. [PubMed]

33. Chiavari, C.; Coloretti, F.; Nanni, M.; Sorrentino, E.; Grazia, L. Use of donkey's milk for a fermented beverage with lactobacilli. Lait 2005, 85, 481-490. [CrossRef]

34. Vincenzetti, S.; Polidori, P.; Vita, A. Nutritional characteristics of donkey's milk protein fraction. In Dietary Protein Research Trends; Ling, J.R., Ed.; Nova Science Publisher Inc.: New York, NY, USA, 2007; pp. 207-225.

35. Vita, D.; Passalacqua, G.; Di Pasquale, G.; Caminiti, L.; Crisafulli, G.; Rulli, I.; Pajno, G.B. Ass's milk in children with atopic dermatitis and cow's milk allergy: Crossover comparison with goat's milk. Pediatr. Allergy Immunol. 2007, 18, 594-598. [CrossRef] [PubMed]

36. Martin, P.; Grosclaude, F. Improvement of milk protein-quality by gene technology. Livest. Prod. Sci. 1993, 35, 95-115. [CrossRef]

37. Vincenzetti, S.; Polidori, P.; Mariani, P.; Cammertoni, N.; Fantuz, F.; Vita, A. Donkey milk protein fractions characterization. Food Chem. 2008, 10, 640-649. [CrossRef]

38. Vincenzetti, S.; Amici, A.; Pucciarelli, S.; Vita, A.; Micozzi, D.; Carpi, F.M.; Polzonetti, V.; Natalini, P.; Polidori, P. A Proteomic Study on Donkey Milk. Biochem. Anal. Biochem. 2012, 1, 109. [CrossRef]

39. Greppi, G.F.; Roncada, P. La componente proteica del latte caprino. In L'alimentazione della Capra da Latte; Pulina, G., Ed.; Avenue Media Publisher: Bologna, Italy, 2005; pp. 71-99.

40. Bertino, E.; Gastaldi, D.; Monti, G.; Baro, C.; Fortunato, D.; Perono Garoffo, L.; Coscia, A.; Fabris, C.; Mussap, M.; Conti, A. Detailed proteomic analysis on DM: Insight into its hypoallergenicity. Front. Biosci. 2010, 2, 526-536. [CrossRef]

41. Chianese, L.; Calabrese, M.G.; Ferranti, P.; Mauriello, R.; Garro, G.; De Simone, C.; Quarto, M.; Addeo, F.; Cosenza, G.; Ramunno, L. Proteomic characterization of donkey milk “caseome”. J. Chromatogr. A 2010, 1217, 4834-4840. [CrossRef] [PubMed]

42. Godovac-Zimmermann, J.; Conti, A.; James, L.; Napolitano, L. Microanalysis of the amino-acid sequence of monomeric beta-lactoglobulin I from donkey (Equus asinus) milk. The primary structure and its homology with a superfamily of hydrophobic molecule transporters. Biol. Chem. Hoppe-Seyler 1988, 369, 171-179. [CrossRef] [PubMed]

43. Godovac-Zimmermann, J.; Conti, A.; Sheil, M.; Napolitano, L. Covalent structure of the minor monomeric beta-lactoglobulin II component from donkey milk. Biol. Chem. Hoppe-Seyler 1990, 371, 871-879. [CrossRef] [PubMed]

44. Herrouin, M.; Molle, D.; Fauquant, J.; Ballestra, F.; Maubois, J.L.; Leonil, J. New Genetic Variants Identified in Donkey's Milk Whey Proteins. J. Protein Chem. 2000, 19, 105-115. [CrossRef] [PubMed]

45. Cunsolo, V.; Saletti, R.; Muccilli, V.; Foti, S. Characterization of the protein profile of donkey's milk whey fraction. J. Mass Spectrom. 2007, 42, 1162-1174. [CrossRef] [PubMed]

46. Kontopidis, G.; Holt, C.; Sawyer, L. Invited review: Beta-lactoglobulin: Binding properties, structure, and function. J. Dairy Sci. 2004, 87, 785-796. [CrossRef]

47. Liang, L.; Tajmir-Riahi, H.A.; Subirade, M. Interaction of beta-lactoglobulin with resveratrol and its biological implications. Biomacromolecules 2008, 9, 50-56. [CrossRef] [PubMed]

48. Liang, L.; Subirade, M. Beta-Lactoglobulin/Folic Acid Complexes: Formation, Characterization, and Biological Implication. J. Phys. Chem. B 2010, 114, 6707-6712. [CrossRef] [PubMed]

49. Permyakova, E.A.; Berliner, L.J. $\alpha$-Lactalbumin: Structure and function. FEBS Lett. 2000, 473, $269-274$. [CrossRef]

50. Pelligrini, A.; Thomas, U.; Bramaz, N.; Hunziker, P.; von Fellenberg, R. Isolation and identification of three bactericidal domains in the bovine alpha-lactalbumin molecule. Biochim. Biophys. Acta 1999, 1426, 439-448. [CrossRef]

51. Hakansson, A.; Svensson, M.; Mossberg, A.K.; Sabharwal, H.; Linse, S.; Lazou, I.; Lonnerdal, B.; Svanborg, C. A folding variant of alpha-lactalbumin with bactericidal activity against Streptococcus pneumoniae. Mol. Microbiol. 2000, 35, 589-600. [CrossRef] [PubMed]

52. Cawthern, K.M.; Narayan, M.; Chaudhuri, D.; Permyakov, E.A.; Berliner, L.J. Interactions of $\alpha$-Lactalbumin with Fatty Acids and Spin Label Analogs. J. Biol. Chem. 1997, 272, 30812-30816. [CrossRef] [PubMed] 
53. Hakansson, A.; Zhivotovsky, B.; Orrenius, S.; Sabharwal, H.; Svanborg, C. Apoptosis induced by a human milk protein. Proc. Natl. Acad. Sci. USA 1995, 92, 8064-8068. [CrossRef] [PubMed]

54. Svensson, M.; Sabharwal, H.; Hakansson, A.; Mossberg, A.K.; Lipniunas, P.; Leffler, H.; Svanborg, C.; Linse, S. Molecular Characterization of $\alpha$-Lactalbumin Folding Variants That Induce Apoptosis in Tumor Cells. J. Biol. Chem. 1999, 274, 6388-6396. [CrossRef] [PubMed]

55. Köhler, C.; Hakansson, A.; Svanborg, C.; Orrenius, S.; Zhivotovsky, B. Protease activation in apoptosis induced by MAL. Exp. Cell Res. 1999, 249, 260-268. [CrossRef] [PubMed]

56. Mossberg, A.K.; Hun Mok, K.; Morozova-Roche, L.A.; Svanborg, C. Structure and function of human $\alpha$-lactalbumin made lethal to tumor cells (HAMLET)-type complexes. FEBS J. 2010, 277, 4614-4625. [CrossRef] [PubMed]

57. Zhang, X.Y.; Zhao, L.; Jiang, L.; Dong, M.L.; Ren, F.Z. The antimicrobial activity of donkey milk and its microflora changes during storage. Food Control 2008, 19, 1191-1195. [CrossRef]

58. Šarić, L.C.; Šarić, B.M.; Kravić, S.T.; Plavšić, D.V.; Milovanović, I.L.; Gubić, J.M.; Nedeljković, N.M. Antibacterial activity of domestic Balkan donkey milk toward Listeria monocytogenes and Staphylococcus aureus. Food Feed Res. 2014, 41, 47-54. [CrossRef]

59. Mao, X.; Gu, J.; Sun, Y.; Xu, S.; Zhang, X.; Yang, H.; Ren, F. Anti-proliferative and anti-tumour effect of active components in donkey milk on A549 human lung cancer cells. Int. Dairy J. 2009, 19, 703-708. [CrossRef]

60. Clementi, E.A.; Wilhelm, K.R.; Schleicher, J.; Morozova-Roche, L.A.; Hakansson, A.P. A complex of equine lysozyme and oleic acid with bactericidal activity against Streptococcus pneumoniae. PLoS ONE 2013, 8, e80649. [CrossRef] [PubMed]

61. Ward, P.P.; Paz, E.; Conneely, O.M. Multifunctional roles of lactoferrin: A critical overview. Cell. Mol. Life Sci. 2005, 62, 2540-2548. [CrossRef] [PubMed]

62. Dial, E.J.; Lichtenberger, L.M. Effect of lactoferrin on Helicobacter felis induced gastritis. Biochem. Cell Biol. 2002, 80, 113-117. [CrossRef] [PubMed]

63. Cornish, J.; Palmano, K.; Callon, K.E.; Watson, M.; Lin, J.M.; Valenti, P.; Naot, D.; Grey, A.B.; Reid, I.R. Lactoferrin and bone; structure-activity relationships. Biochem. Cell. Biol. 2006, 84, 297-302. [CrossRef] [PubMed]

64. Sinha, M.; Kaushik, S.; Kaur, P.; Sharma, S.; Singh, T.P. Antimicrobial Lactoferrin Peptides: The Hidden Players in the Protective Function of a Multifunctional Protein. Int. J. Pept. 2013, 2013, 390230. [CrossRef] [PubMed]

65. Jenssen, H. Antimicrobial activity of lactoferrin and lactoferrin derived peptides. In Dietary Protein Research Trends; Ling, J.R., Ed.; Nova Science Publisher Inc.: New York, NY, USA, 2007; pp. 1-62.

66. Tenovuo, J.O. The peroxidase system in human secretions. In The Lactoperoxidase System: Chemistry and Biological Significance; Pruitt, K.M., Tenovuo, J.O., Eds.; Marcel Dekker: New York, NY, USA, 1985; pp. 101-122.

67. Tanaka, T. Antimicrobial activity of lactoferrin and lactoperoxidase in milk. In Dietary Protein Research Trends; Ling, J.R., Ed.; Nova Science Publisher Inc.: New York, NY, USA, 2007; pp. 101-115.

68. Shin, K.; Wakabayashi, H.; Yamauchi, K.; Teraguchi, S.; Tamura, Y.; Kurokawa, M.; Shiraki, K. Effects of orally administered bovine lactoferrin and lactoperoxidase on influenza virus infection in mice. J. Med. Microbiol. 2005, 54, 717-723. [CrossRef] [PubMed]

69. Shin, K.; Hayasawa, H.; Lönnerdal, B. Purification and quantification of lactoperoxidase in human milk with use of immunoadsorbent with antibodies against recombinant human lactoperoxidase. Am. J. Clin. Nutr. 2001, 73, 984-989. [PubMed]

70. Tenovuo, J.; Moldoveanu, Z.; Mestecky, J.; Pruitt, K.M.; Rahemtulla, B.M. Interaction of specific and innate factors of immunity: IgA enhances the antimicrobial effect of the lactoperoxidase system against Streptococcus mutans. J. Immunol. 1982, 128, 726-731. [PubMed]

71. Arnold, R.; Russell, J.E.; Devine, S.M.; Adamson, M.; Pruitt, K.M. Antimicrobial activity of the secretory innate defence factors lactoferrin, lactoperoxidase and lysozyme. In Cardiology Today; Guggenheim, B., Ed.; S. Karger: Basel, Switzerland, 1984; pp. 75-88.

72. Silva, S.V.; Malcata, F.X. Caseins as a source of bioactive peptides. Int. Dairy J. 2005, 15, 1-15. [CrossRef]

73. Minervini, F.; Algaron, F.; Rizzello, C.G.; Fox, P.F.; Monnet, V.; Gobbetti, M. Angiotensin I-converting-enzymeinhibitory and antibacterial peptides from Lactobacillus helveticus PR4 proteinase-hydrolyzed caseins of milk from six species. Appl. Environ. Microbiol. 2003, 69, 5297-5305. [CrossRef] [PubMed] 
74. Notredame, C.; Higgins, D.G.; Heringa, J. T-Coffee: A novel method for fast and accurate multiple sequence alignment. J. Mol. Biol. 2000, 302, 205-217. [CrossRef] [PubMed]

75. Maruyama, S.; Suzuki, H. A peptide inhibitor of angiotensin I-converting enzyme in the tryptic hydrolysate of casein. Agric. Biol. Chem. 1982, 46, 1393-1394. [CrossRef]

76. Pihlanto-Leppala, A.; Rokka, T.; Korhonen, H. Angiotensin I converting enzyme inhibitory peptides from bovine milk proteins. Int. Dairy J. 1998, 8, 325-331. [CrossRef]

77. Parker, F.; Migliore-Samour, D.; Floch, F.; Zerial, A.; Werner, G.H.; Jollès, J.; Casaretto, M.; Zahn, H.; Jollès, P. Immunostimulating hexapeptide from human casein: Amino acid sequence, synthesis and biological properties. Eur. J. Biochem. 1984, 145, 677-682. [CrossRef] [PubMed]

78. Tesse, R.; Paglialunga, C.; Braccio, S.; Armenio, L. Adequacy and tolerance to ass's milk in an Italian cohort of children with cow's milk allergy. Ital. J. Pediatr. 2009, 35, 19. [CrossRef] [PubMed]

79. Giovannini, M.; D’Auria, E.; Caffarelli, C.; Verduci, E.; Barberi, S.; Indinnimeo, L.; Iacono, I.D.; Martelli, A.; Riva, E.; Bernardini, R. Nutritional management and follow up of infants and children with food allergy: Italian Society of Pediatric Nutrition/Italian Society of Pediatric Allergy and Immunology Task Force Position Statement. Ital. J. Pediatr. 2014, 40, 1. [CrossRef] [PubMed]

(C) 2017 by the authors. Licensee MDPI, Basel, Switzerland. This article is an open access article distributed under the terms and conditions of the Creative Commons Attribution (CC BY) license (http://creativecommons.org/licenses/by/4.0/). 